\title{
Review on the Studies of Unearthed Mawangdui Medical Books
}

\author{
Liu Chunyu \\ Institute of Chinese Language and Literature, Southwest University, Chongqing, China \\ Email: 48264246@qq.com, yu2028@163.com
}

Received 27 December 2015; accepted 25 January 2016; published 28 January 2016

Copyright (C 2016 by author and Scientific Research Publishing Inc.

This work is licensed under the Creative Commons Attribution International License (CC BY). http://creativecommons.org/licenses/by/4.0/

(c) (i) Open Access

\begin{abstract}
Mawangdui medical books are the most authoritative ones among its field. It's attracted wide attention from the outside world since 1973. So far, researchers have accomplished fruitful results studying them. The goal of this article is to review the previous studies and summarize all the achievements and shortcomings then provide some possible solutions.
\end{abstract}

\section{Keywords}

Mawangdui, Medical Books, Research Results, Existing Problem, Solution

\section{Introduction}

The discovery of Mawangdui Tomb of Changsha is one of the most significant events of the 20th Century in both archeology and culture world, one of the most important discoveries of this excavation is a group of ancient medical books which in the following chapters will be addressed as Mawangdui medical books. These medical books were all lost books, that is to say, there aren't physical versions survived today, due to the abstruse and sophisticated contents, those books aroused widespread concerns since then. For the past forty years, researchers have accomplished fruitful results studying them, yet retrospective studies are still rare. It has been four decades since those medical books had been excavated, so we collect the relevant research results and classified them into different categories in order to have a more comprehensive and clear understanding for the early studies, then we can summarize some problems that still exist and propose some possible solutions.

By the end of 1973, the eastern outskirts of Changsha, Hunan province, Mawangdui III tomb unearthed a large number of silk manuscripts and some bamboo slips. Part of the bamboo slips can be classified as prescriptional documents; they have about twenty thousand words, covering diagnostics, acupuncture, Jingmai-xue, pharmaceutics, health preservation and fertility studies. Since neither titles nor name of the authors can be found when they were unearthed, so the research group divided all those books into fifteen kinds and named them as 
follows: Hand-foot-11 by Moxibustion (hereafter called Zu Bi 足臂), Yin and Yang Moxibustion by 11 book A (hereafter called Yin Yang book A 阴阳十一脉炎经), Pulse Law (脉法), Death Syndromes of Yin and Yang pulses (hereafter called Death Syndromes 阴阳脉死候), Prescriptions of fifty-two diseases (hereafter called Prescriptions 病方), Que Gu Shi Qi (却谷食气), Yin and Yang Moxibustion by 11 book B (hereafter called Yin Yang B 阴阳乙本), Guide map (导引图), Healthcare Prescriptions (养生方), Miscellaneous Cure (杂疗 方), Births book (胎产书), Ten Questions (十问), Yin and Yang in one (合阴阳), On Principle of Universe (天下至道谈), Miscellaneous banned prescriptions (杂禁方). And the Miscellaneous banned prescriptions were written on wooden slips, Ten Questions, Yin and Yang in one, On Principle of Universe were copied on silk book.

\section{Review the Studies for the Past Four Decades}

Mawangdui medical books have been explored for forty years and researchers have achieved many remarkable results studying them. Based on writer's statistics, by November 2014, there were already more than ten monographs and hundreds of papers in related studies, we are now going to review all those domestic and international research results retrospectively.

\subsection{Domestic Research}

\subsubsection{Informative Monograph}

In 1974, a research group was formed to analyze Mawangdui medical books and that very Prescriptions of fiftytwo diseases (Mawangdui Han Danasty Tomb bamboo books research group, 1979) was published at the same year, another book published at the same year was Ma Wang Dui Han Tomb Texts-Derivation Graph (Mawangdui Han Danasty Tomb bamboo books research group, 1979). In 1985, Mawangdui Han Tomb Silk Book IV (Mawangdui Han Danasty Tomb bamboo books research group, 1985) was published and this book contained all the charts and explanations of Mawangdui medical book and corrected certain parts of the previous edition also. The publication of this book had significant meanings, it provided researchers authentic interpretation for the past forty years; Changsha Mawangdui Han Tomb Field Archaeological Report Writing (Hunan Institute of Archaeology, 2004), came out in 2004, with explanations of the following ones: Ten Questions, Yin and Yang in one, On Principle of Universe, Miscellaneous banned prescriptions; In 2014, The Integration of Mawangdui Bamboo silk books (hereafter called The integration) (Qiu Xigui, 2014) came out, this book rearranged and interpreted all documents patterns and annotations of all the documents in this subject, its also announced the latest research results, included the then latest results. It's the most accurate and comprehensive edition.

\subsubsection{Research Monograph}

Right after the publication of the rearranged charts and interpretations of the medical books, researches in many countries took great interest in them. At the domestic level, there are five main monographs which studied on those medical books from the linguistic angle. In 1988, Mawangdui Medical Books Test Notes (Zhou Yimou \& Xiao Zuotao, 1988) was first published, this book had a complete style and clear interpretations yet also had some questionable proofreading; In 1992, Interpretation on Mawangdui medical books (Ma Jixing, 1992) was published and this book did a thoroughly research on repairing and correcting the residual texts; Proof and Explanation about Mawangdui Medicine books (I) (II) (Wei Qipeng \& Hu Xianghua, 1992) published in same year, this book did a basic introduction from medical standpoint yet didn't lack of interpretation; In 1995, Mawangdui Medical books (Lu Zhaolin \& Huang Zuozhen, 1995) was published and this concise book didn't discuss too much about pervious contentious issues; In 2014, The Collation for Bamboo and Silk documents (Zhou Zuliang \& Fang Yilin, 2014) was published and this book did a thoroughly proofreading and corrected some mistakes, this book is available for reference in studying those medical books; In addition all of those, The Additional Interpretation For Prescriptions Of Fifty-two Diseases (Yan Jianmin, 2005) supplemented some of the missing parts yet the proofreading were not rigorous enough.

Besides monographs, related papers can also be found in some medical periodicals such like the Mawangdui Medical books (Mawangdui medical books research group, 1980 \& 1981) and Mawangdui Research Collection (Hunan Provincial Museum, 1994). Among all the unearthed books, Mawangdui medical books are the focus of most attentions, such as Zhangshou ren's Medical On Set (Zhang Shouren, 2000) studied the book Prescriptions 
of Fifty-two Diseases; In Bamboo-silk Drug Name Research (Zhang Xiancheng, 1997) Zhangxiancheng categorized the drug names comprehensively; In Medical Term research in Qin-Han dynasty (Zhang Xiancheng, 2000). and Glossary of medical term in Qin-Han Dynasty (Zhang Xiancheng, 2002) scholars also studied medical terms among those unearthed medical books thoroughly and comprehensively.

\subsubsection{Papers}

Because Mawangdui medical books were transcribed either on bamboo or silk and many parts had been severely damaged when they were dug up, plus, lacking of physical versions also contributed their research values. Besides monographs, single papers discussed from specific angles are also many. We are now going to illustrate all of the early studies in different respect.

\section{1) Documentaries articles and other reference studies}

Early before the publication of Mawangdui medical book's research materials, the research group had already published several relevant articles. In 1975, the sixth edition of the Journal Cultural relic published The Interpretation of unearthed Mawangdui Medical books I, this article released the annotations of Guide Map, Que Gu Shi Qi, Yin and Yang, Pulse Law, Death Syndromes; In same year, the ninth edition published The Interpretation of unearthed Mawangdui Medical books II, released the annotation ofPrescriptions; In 1981, Zhoushirong published The Interpretation of Changsha No.3 Han Tomb Bamboom book Healthcare Prescriptions and this article released the annotations of Ten Questions, Yin and Yang in one, Miscellaneous banned prescriptions. There are also some articles trying to explain and interpret those medical books like Huangchangjie’s “阴阳脉死候”释译, Mao Liang, 古医书〈脉法〉诠释, Wu Zhichao, 〈却谷食气篇〉初探, Liu Shijing “却谷食气”试释, Wei Qipeng 帛书〈却谷食气篇〉研究 etc.

\section{2) Studies on words}

As no physical versions of those medical books survived and no one knew their existence till few decades ago, what's more, all the characters were written either on bamboos or silks, so identify the original scriptures is really difficult. In order to understand them better, a large number of scholars joined into this team. Order generation linguists like Lu Zongda (Lu Zongda, 1981), Qiu Xigui and newer generation ones like Liu Zhao, Zhang Xiancheng, Chen Jian, and Meng Pengsheng. Professor Qiu made great contributions in translating those books (Qiu Xigui, 1987) and Meng Pengsheng made lots of detailed and convincing researches too (Meng Pengsheng, 2003); Through carefully proofreading the photos; Chen Jian (Chen Jian, 2013) supplemented the interpretation from the original text, so that the “病方” and “养生方” have more accurate and reliable interpretations than before; Liu Zhao 刘钊 studied 牧牧 (Liu Zhao, 1994) in Zu Bi 足臂 and 龟、虫 (Liu Zhao, 1997) in Bing Fang 病方 with phonology theory and medical knowledge then came to the conclusion that 牧牧 is supposed to read as 瞢瞢 and 龟、虫 are supposed to be 桑虫. Some famous Chinese physicians like Shi Changyong 史常永 (Shi Changyong, 1993), Zhao Youchen 赵有臣 (Zhao Youchen, 1981), Ren Yingqiu 任应秋 (Ren Yingqiu, 1984), He Zongyu 何宗禹 (He Zongyu, 1981) are also engaged in this effort and their results are also contribute the current research from different angles.

All those researches were mainly focused on naming the drug names, because lots of drugs had been named as same names which made reading those medical books became harder, so studying their names are extremely important. So far as the status the most foremost expert is professor Zhang Xiancheng, besides all those books we mentioned above, he also wrote many articles which combined with critical interpretation, phonology and medicine knowledge. Take 简帛医书药名释读续貂 (甘肃中医学院学报 1994) for example, professor Zhang corrected five groups of interpretations of drug names, following are the conclusions: 1)毚炶实,兔骨实, based

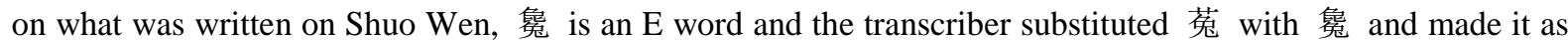
菟纫实，炶 and 芦 both pronounced as 卢 so their sounds can be altered, plus, 实 means “the seed" which explained why 觚丝实 is 菟丝子; what’s more, 兔 is the phonetic element of 菟 which also explained 兔 骨实 is 菟丝子; (2)禹灶, 禹熏 and 乾夸灶 are 伏龙肝: because 禹 is the borrowed word of 矩, and 灶, 熏are 灶土, 熏土, and 夸 is 大 which explained why the above three are all 伏龙肝; (3)要苦 is 紫藏: because of

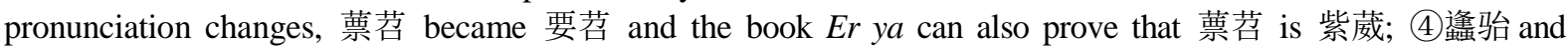
黄蜂骀 are 蜂子: 冷 and 蜂 are gu jin zi (ancient and modern word), 蜂骀 and 蜂子 are result of pronunciation changes; (5)遗弱 is the fresh human urine: by the methods of exegetics 遗 has the meaning of "to excrete" which is why 弱 means 溺 and 遗弱 means "fresh human urine”; (6)牡狗 and 牡蝼 are 蝼蛄: 杜 miswrote as 牡, and 杜狗 and 杜蝼 are two written forms of one pronunciation, they are all synonyms of 蝼蛄. 
Another article 马王堆佚医书释读札记(《简帛研究》1996) studied seven words which were either misinterpreted or didn’t be interpreted in Mawangdui medical books, 再食棌、茜酨、桯、葦、并符、沘、饍.

Besides those, 简帛医书中的中药异名(《医古文知识》, 1994) collected 57 synonyms from the medical books and marked their phonology positions, this helped in a significant way to understand Mawangdui medical books; 马王堆医书药名“汾困”试考(《中华医史杂志》, 1996) proved 汾困 is 香萆 from both exegetics and medical perspectives yet successfully solved this problem; Similar articles also have 马王堆医书药名试考(《湖 南中医药大学学报》, 1996), 马王堆医书疑难药名考释二则 (《甘肃中医学院学报》, 1996), 简帛医书中 的中药异名(续一)(《中医药文化》, 1997 and 〈马王堆古医书考释〉补正, (《湖南省博物馆四十周年纪念 论文集》, 湖南教育出版社, 1996) etc.

Speaking of naming drugs, another name we must mention is Sun Qiming, since last eighty's he published series of papers discussing drug names about Prescriptions of fifty-two diseases, mainly includes: 为〈五十二病方〉 “久脂”补注( 《中医杂志》, 1982), quoted from Yupian (玉篇) and Bielu (别录) and proved 久脂 is 膈脂 which is “cool-preserved lard”; 〈五十二病方〉 “膏、脂”释义 (《中成药研究》1983), this article quoted from ShuoWen (说文) “戴角者脂, 无角者亳” and then distinguished the meaning of 膏 and 脂; 〈五十二病方〉仆 纍考 (《中成药》, 1983) quoted from Bencao Gangmu (本草纲目) and interpreted 仆纍 as 蜗牛; 〈五十二病 方〉骆阮、白苦、苦浸考 (《中成药》, 1984), based on the explanations from some definitive ancient dictionaries and combined the actual curative effect of medicine then reached the conclusion that 骆阮, 白苦 and 苦浸 are all synonyms of 苦参; 〈五十二病方〉鹊棠考辨(《中华医史杂志》, 1995 年 4 期), this article believed the character of 棠 is the miswriting form of 巢 and 鹊棠 is supposed to be 鹊巢; 〈五十二病方〉 “麇芜本” 别释(《中华医史杂志》, 1997), this article listed several entries from Shan Hai Jing (山海经) and proved 麇芜 本 was an extinct plant; 帛书“茜荚”别释(《中华医史杂志》, 2000) and 莤荚考辨(《医古文知识》, 2001), those two articles thought that 茜荚 is the miswriting form of 茜茅 and 茜茅 should be 萧茅, meaning “twitch-grass which had been used as sacrificial offerings”; 〈五十二病方〉药物选释(《浙江中医药大学学报》, 1987), this article studied several drug names of “冥虫种”.

As for Guide map (导引图), Shentao published three articles on the first, third and ninth issues of Wenwu (文 物) respectively in 1979, they are 谈西汉帛画〈导引图〉中的“猫䟱”, 谈西汉帛画〈导引图〉中的“引胠积” and 谈西汉帛画〈导引图〉 中的“引烦”, those three articles discussed 俩欮, 引胠积 and 烦 three surgical

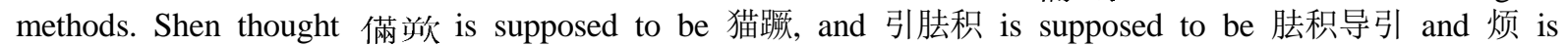
supposed to be 引烦. He then published another article in the following year 西汉帛画〈导引图〉解析(《文物》, 1980.9) and made a detailed research to all the surgical methods in Guide map (导引图); As for the word 引胠积, there are two articles which were written by Li Jinyong, 谈帛画〈导引图〉 中的“胠积”(《文物》, 1978) and 马 王堆汉墓出土帛书〈导引图〉 中“胠积”病考(《读古医书随笔》, 北京人民卫生出版社, 1984), another one written by Wang Jianmin 帛画〈导引图〉 中的“引胠积”及今用(《浙江中医药大学学报》, 1989). About 熊经, 满欮 and 鹞北, there are “熊经”质疑(《齐鲁学刊》, 1988 年第 5 期) written by 施观芬, “熊经”新解 (《古汉 语研究》, 1995) written by 李怀之, 帛书导引图题记“满欮”考》(《古汉语研究》, 1994.2) written by 廖名春,

〈导引图〉题记“䍃北”浅议(《湖南省博物馆馆刊》第六辑, 2010) written by 王卉; About the book Yang Shengfang (养生方), related articles are 《〈养生方〉阙文试补》(《湖南中医杂志》, 1985) written by 孙光荣, 马王堆帛书〈养生方〉 “加”义明辨( 《成都中医药大学学报》1995) written by 倪世美，〈养生方〉 “等”义质疑 (《成都中医药大学学报》, 1997) written by 宋兴; About the book Shi Wen 十问, there are 马王堆三号墓竹简 〈十问〉注释补正(《考古》, 1994.5) written by 连劭名的, 马王堆医书〈杂疗方〉考辨(《湖南中医药大学 学报》, 1989) written by 潘远根, 马王堆医书注释辨疑(《湖南中医药大学学报》, 1992) written by 龙月云.

Since the inception of the new century, many young teachers and PhD students also joined in this field, like Liu Yuhuan 刘玉环, Luo Baozhen 罗宝珍 and Yang Yanhui 杨艳辉 etc. In 马王堆帛书药名补释五则(《昆明 学院学报》, 2011.2) Liu Yu Huan 刘玉环 studied 产齐赤, 邑束 and 邑鸟卵; In 马王堆简帛、张家山汉简文 字考释 5 则(《福建中医药大学学报》, 2011.3), LuoBaoZhen 罗宝珍 integrated information of exegetics and phonology and reinterpreted 人病马不间 and several other phrases, this article provides sufficient information and has strong convincingness; In〈马王堆汉墓帛书(肆)〉补释(《贵州师范大学学报》, 2013) Liu Yuhuan 刘 玉环 added 15 interpretations for the original text; In 简帛医书所见“仆累”辨析(《江海学刊》, 2014) Yang Yanhui 杨艳辉 combined medical methods, phonetic principles and exegesis knowledge and came to the conclusion that 仆累 is 螺; Besides those, there are also “焀”字考证(《中医药文化》, 2007) written by 刘庆宇, 释“疛”疾(《福建省辞书学会第五届会员代表大会暨第十九届年会论文集》, 2009) written by 罗宝珍, 读〈养 生方〉札记(《湖南省博物馆馆刊》, 2010) written by 王卉, 马王堆汉墓医书〈十问〉札记一则(《湖南省 
博物馆馆刊》第六辑 2010) written by 范常喜, 〈马王堆汉墓帛书(肆)〉释文校勘答记(《第二十一次中医经 典文本及医古文研究学术交流会论文集》, 2012) written by 周祖亮.

\section{3) Studies on vocabulary}

There aren’t many articles which studied on vocabulary so far, mainly 马王堆医书中的新兴量词(《湖南省博物 馆馆刊》第二期, 2005) written by Zhang Xiancheng 张显成, this article discussed 13 newly emerged measure words; 〈五十二病方〉 物量词举隅(《古汉语研究》, 1998) written by Zhang Lijun 张丽君, this article did a longitudinal study on 果、枚、梃、把、束、撮(they are all material measure words); 帛书〈五十二病方〉数量词 研究(《简帛语言文字研究》第一辑, 巴蜀书社, 2002) co-written by Zhang Junzhi 张俊之 and Zhang Xiancheng 张显成, this article sorted all the numerals and measure words in Prescriptions of fifty-two diseases (病方).

\section{4) Studies on grammar}

Articles about this type are as follows: 马王堆汉墓帛书(肆)所见称数法考察(《古汉语研究》, 1997) written by Xu Lili 徐莉莉, this article did a thoroughly review and studied all the material unit words, action unit words, fractional number, proportion, and approximate numbers in Mawangdui medical books; 〈马王堆汉墓帛 书 (肆)〉 “数·量·名” 形式发展探析(《中文自学指导》, 2003), written by Chen Jinzhu 陈近朱, this article had a considerable research on the numeral-classifier compounds in Mawangdui medical books; 〈马王堆汉墓帛 书〉所反映的上古动补式(《辽宁大学学报》, 2005) written by 肖贤樹, this article had a comprehensively and systematically discussion on the verb-complement pattern and some other relevant patterns which showed up in the Prescriptions of fifty-two diseases (病方) and Healthcare prescriptions (养生方, this article also had an explanation about the coexistence of those patterns; 马王堆汉墓帛书中的疑问范畴(《古汉语研究》, 2009), written by Guo Xiaohong 郭晓红的, this article discussed different types of the category of question markers.

\section{5) Other studies}

Besides the above studies, there are also some others similar articles, such as 〈五十二病方〉语言初探(《陕 西中医》, 1984.3), written by CuiXizZhang 崔锡章; this article studied the Borrowed words(假借字) in 病方 from three different aspects; 〈五十二病方〉的文字通用及研究意义》(《四川中医》, 1992), written by Li Shutian 李书田,this article studied the variant characters, borrowed words and ancient-modern words; 帛书〈阴 阳十一脉尒经〉甲、乙本异文考察》(《中国文字研究》, 2001), written by XuLiLi 徐莉莉, this article discussed the variants texts between the two books of Ying-Yang (阴阳); 马王堆古医书异文通用说略(《国医 论坛》, 2008), written by 李书田.

\section{6) Dissertations}

Over the past decade, the number of master and doctoral dissertations specialized on Mawangdui medical book’s language have gradually increased: Wang Jianmin 王建民 (Wang Jianmin, 2002), He Limin 何丽敏 (He Limin, 2007) and Guan Junjie 管骏捷 (Guan Junji, 2011), they studied the folk characters, interchangeable characters and drug names in Mawangdui medical books; Also, Zhang Zhengxia 张正霞 (Zhang Zhengxia, 2003) studied the word-formation in Prescriptions of fifty-two diseases(病方), Du Feng 杜峰 (Du Feng, 2011) investigated all the drug names related with 茱英; Wu Yunyan 吴云燕 (Wu Yunyan, 2006) made a classified discussion on the commonly used words in Mawangdui medical books; other studies like 两汉简帛异体字研究 (Wang Yujiao, 2013), 简帛病症文字研究 (Luo Baozhen, 2011), 楚地秦汉简牍字词论考 (Lu Fangge, 2013) and 简帛医籍词语研究 (Zhou Zuliang, 2012) all can be categorized in the same field.

\subsection{Studies from Overseas}

The excavation of Mawangdui medical books also attracted the attention of many foreign scholars, there have been unearthed from the research monographs, papers come out.

\subsection{Monographs}

\subsubsection{Japan}

Classified index for the characters in Mawangdui unearthed medical books. 马王堆出土医书字形分类索引 (Emura Haruki, 1987), written by Emura Haruki 江村治树; General Index for the interpretations on meridian vessel of Mawangdui medical books (IV) and Zhangjiashan Han Tomb bamboo books 〈马王堆汉墓帛书〉肆、

〈张家山汉墓竹简〉所取十一经脉释文总索引 (Kobayashi Kenji, 2004), written by Kobayashi Kenji 小林健 二; Collections of the translation and interpretation on Mawangdui unearthed books. 马王堆出土文献译注丛书 ——五十二病方(Co-authored by Hiroshi Kosoto \& Hasebe Echi \& Senjuro Machi, 2007), written by Hiroshi Kosoto 小曾户洋; New discovery一Study on China's science information. 新发现中国科学史资料的研究 
(Yamada Keiji, 1985), written by Yamada Keiji 山田庆儿.

\subsubsection{America}

Translation and annotation on Mawangdui medical books 马王堆医书译注 (English edition) Donald Harper 夏 德安 (Donald Harper, 1998).

\subsection{Papers}

\subsubsection{Japan}

The grammar features of Fifty-two Diseases 帛书〈五十二病方〉的语法特点 (Onishi Katsuya, 1994), Onishi Katsuya 大西克也; 〈足臂十一脉尒经〉和〈阴阳十一脉尒经〉 (Akahori Akira, 1990), translated and annotated by Akahori Akira 赤堀昭; 有关道家的〈导引图〉的研究——文字解读与体操姿态(Fukuyado, 1992), written by Fukuyado 福宿孝夫; Notes on the Derivation Graph from Mawangdui Han Tomb silk books. 马王堆汉墓帛 书〈导引图〉整理琐记(三题) (Hirose Kunio, 2013), written by Hirose Kunio 广濑熏雄.

\subsubsection{America}

Fifty-two Disease and Yue prescriptions. 五十二病方与越方[47], written by Donald Harper 夏德安, translated by 陈松长(Donald Harper \& Chen, 1994); Translation \& Review on Fifty-two Diseases 马王堆三号墓出土文献之 一医书(Donald Harper, 1976) and 五十二病方：翻译和综述(Donald Harper, 1982), written by Donald Harper.

\section{Existential Problem and Possible Solution}

\subsection{Existential Problem}

Ever since its excavation, researchers have done lots of remarkable achievements, yet we are still facing some problems which summarized as follows:

\subsubsection{Interpretation Is Difficult}

For the past forty years researchers have been diligently working on collating and interpretation and achieved remarkable results, however, due to its multifarious contents and used to be severely derogated, plus, the variant forms of characters, there are still lots of doubtful words and phrases need to be interpreted. Besides, the physical versions of those medical books were lost in history so it is almost impossible to find their related reference books which can explain the difficulty of interpreting them. For words which have already been interpreted, due to the limited materials the correctness of the conclusion also needs further validation.

\subsubsection{Limited Research Method}

Not only researchers must have in-depth knowledge on philology, they must also familiar with medical theory due to the peculiar particularity of those medical books. Experts from diversified fields have done a large number of researches, however, generalists who are proficient in all those referenced subjects are still rare which contribute the limitation of current studies.

\subsubsection{No Comprehensive Treatises Have Been Made Yet}

Research results about Mawangdui medical books are massive both at home and abroad, however, those books and articles are scattered across different journals around the world, not to mention their long span of publishing years which explained why it is so hard for researchers to have a clear yet full-scale perspective. So a comprehensive treatises which collects all the previous studies is in urgent need now.

\subsection{Possible Solutions}

Based on the above discussions and some of the problems we are still facing, we now come up with some possible solutions, hopefully can be useful.

\subsubsection{Integrating and Collaborating}

Like we discussed above, researchers must be experts at both sides, so the central task at present is to integrating 
different fields and cultivating all-round talents, only by doing so can we break down the current barriers. The newly published Ji Cheng is exactly the very book we need, it has high quality interpretation and standard charts. The publishing of this book has a realistic and reference meaning to the study of Mawangdui medical books. So closer cooperation and more academic exchanges are still needed, only by doing so can we can find innovative solutions to difficult issues and achieve ideal results.

\subsubsection{Strengthening International Exchanges and Cooperation}

The excavation of Mawangdui medical books not only aroused the interests of Chinese scholars, many Japanese and American scholars are also put great efforts in it. However, different cultural backgrounds may also differentiate people's perspective, which is why we should give enough attention to all the results domestic and international. Therefore, more international symposiums need to be held if we want achieve further and comprehensive achievements.

\subsubsection{Cultivating and Enlarging}

The study of Mawangdui medical books requires all-round talents yet people like that are still rare now, so we need to cultivate a number of highly qualified personnel. "we need to find out more young people who have intense interest in unearthed medical books and solid foundation on medicine and ancient Chinese Documents, we can either send them to graduate school or help them further study the related knowledge. Later on they can apply what they learnt from school to the actual research and enhance their abilies.” (Zhang Ruqing, 2008).

\subsubsection{Summarizing and Synthesizing}

Only one book Ji Cheng cannot include all the previous studies due to its limited length, which further emphasized the importance of summarizing and synthesizing the early researches. According to the authentic news, Professor Zhang Xiancheng and his team from Southwest University is doing this now, we look forward to their success.

\section{References}

Akahori Akira 赤堀昭, 译注 (1990). 《足臂十一脉尒经》和《阴阳十一脉炎经》. [Hand-Foot-11 by Moxibustion and Yin and Yang Moxibustion by 11]. 中华全国首届马王堆医书学术讨论会论文集 [Paper Compilation on the First National Mawangdui Medical Books Academic Symposium], Scientific Research Department in Hunan College of Traditional Chinese Medicine.

Chen Jian 陈剑 (2013). 马王堆帛书《五十二病方》、《养生方》释文校读札记. [Notes on Fifty-Two Diseases \& YangShengFang]. 出土文献与古文字研究, 复旦大学出土文献与古文字研究中心编, [Centre for Unearthed Document \& Ancient Writing of Fudan University], Shanghai: Shanghai Chinese Classics Publishing House.

Donald Harper 夏德安 (1976). 马王堆三号墓出土文献之一一医书《古代中国》第二辑. [Medical Book一No.3 Tomb Mawangduiunearthed Document]. Cambridge: Cambridge University Press.

Donald Harper 夏德安 (1982). 五十二病方：翻译和综述. [Translation \& Review on Fifty-Two Diseases]. Oakland, CA: University of California.

Donald Harper 夏德安 (1994). Chen Songchang 陈松长, 译. 五十二病方与越方. [Fifty-Two Disease and Yue Prescriptions]. 马王堆汉墓研究文集, [Studies on Mawangdui Han Dynasty], Changsha: Hunan Press.

Donald Harper 夏德安 (1998). 马王堆医书译注. [Translation and Annotation on Mawangdui Medical Books]. New York: Columbia University Press.

Du Feng 杜峰 (2011). 五十二病方及其所载 “茱䒱” 相关药名考噰. [Study and Comparison on 茱英 and Other Cases in Fifty-Two Disease]. Beijing: Beijing University of Chinese Medicine.

Emura Haruki 江村治树 (1987). 马王堆出土医书字形分类索引. [Classified Index for the Characters in Mawangdui Unearthed Medical Books]. Suita: Department of Literature Kansai University, You Jiu Publishing House.

Fukuyado 福宿孝夫 (1992). 有关道家的〈导引图〉的研究——文字解读与体操姿态. [Study on Derivation Graph from Taoists' Perspective] (p. 72). Miyazaki: Faculty of Education of University of Miyazaki.

Guan Junji 管骏捷 (2011). 马王堆古医书病名、药名例释. [Illustration on Drug Names and Disease Names from Mawangdui Medical Books]. Shanghai: East China Normal University.

He Limin 何丽敏 (2007). 马王堆史书、医书通假字研究. [Studies on the Borrowed Words from Mawangdui Medical 
Books]. Chongqing: Southwest University.

He Zongyu 何宗禹 (1981). 马王堆医书考证译释问题探讨. [Study on the interpretation for Mawangdui medical books]. Chinese Journal of Medical History.

Hirose Kunio 广濑熏雄 (2013). 马王堆汉墓帛书《导引图》整理琐记 (三题). [Notes on the Derivation Graph from Mawangdui Han Tomb Silk Books]. Shanghai: Shanghai Chinese Classics Publishing House.

Hiroshi Kosoto, Hasebe Echi, \& Senjuro Machi, 小曾户洋, 长谷部英一, 町泉寿郎, 合著 (2007). 马王堆出土文献译注 丛书一一五十二病方. [Collections of the Translation and Interpretation on Mawangdui Unearthed Books]. Tokyo: Joint-Stock Company.

Hunan Institute of Archaeology 湖南考古研究所 (2004). 长沙马王堆二、三号汉墓. 第一卷田野考古发掘报告. [The 2004 Changsha Mawangdui No. Two, Three \& First Volume Fieldwork of Archaeological Report]. Beijing: Cultural Relics Press.

Hunan Provincial Museum 湖南省博物馆编 (1994). 马王堆汉墓研究文集. [Research Anthology for Mawangdui Han Dynasty Books]. Changsha: Hunan Press.

Kobayashi Kenji 小林健二 (2004). 《马王堆汉墓帛书》肆、《张家山汉墓竹简》所取十一经脉释文总索引. [General Index for the Interpretations on Meridian Vessel of Mawangdui Medical Books (IV) and Zhangjiashan Han Tomb Bamboo Books]. Daito Bunka University Institute for Human Sciences.

Liu Zhao 刘钊 (1994). 关于马王堆和张家山出土医书中两个词语解释的辨正. [Correction on Two Words from Mawangdui and Zhangjiashan Unearthed Medical Books]. Journal of Ancient Books Collation and Studies.

Liu Zhao 刘钊 (1997). 马王堆帛书《五十二病方》中一个久被误释的药名. [Correction on a Long Misinterpreted Disease Name in Fifty-Two Diseases]. Journal of Ancient Books Collation and Studies.

Lu Fangge 路方鸽 (2013). 楚地秦汉简牍字词论考. [Studies on Words from Han Bamboo Books]. Hangzhou: Zhejiang University.

Lu Zhaolin, \& Huang Zuozhen 鲁兆麟, 黄作阵 (1995). 马王堆医书. [Mawangdui Medical Books]. Shenyang: Science and Technology Press.

Lu Zongda 陆宗达 (1981). 长沙马王堆医书训释札记. [Note on Changsha Mawangdui Medical Books]. General Introducing for ShuoWenJieZi.

Luo Baozhen 罗宝珍 (2011). 简帛病症文字研究. [Study on Disease Name Characters in Bamboo and Silk Books]. Fuzhou: Fujian Normal University.

Ma Jixing 马继兴 (1992). 马王堆古医书考释. [Study on Mawangdui Medical Books]. Changsha: Hunan Science and Technology Press.

Mawangdui Han Danasty Tomb Bamboo Books Research Group 马王堆汉墓帛书整理小组合编 (1979). 五十二病方. [Prescriptions of Fifty-Two Diseases]. Beijing: Cultural Relics Press.

Mawangdui Han Danasty Tomb Bamboo Books Research Group 马王堆汉墓帛书整理小组合编 (1979). 马王堆汉墓帛 书——导引图. [Mawangdui Han Tomb Texts—Derivation Graph]. Beijing: Cultural Relics Press.

Mawangdui Han Danasty Tomb Bamboo Books Research Group 马王堆汉墓帛书整理小组合编 (1985). 马王堆汉墓帛 书[肆]. [Mawangdui Han Dynasty Tomb Bamboo Books (IV)]. Beijing: Cultural Relics Press.

Mawangdui Medical Books Research Group 马王堆医书研究组 (1980, \& 1981). 马王堆医书研究专刊. [Monograph for Mawangdui Medical Books]. Changsha: Journal of Hunan College of Traditional Chinese Medicine.

Meng Pengsheng 孟蓬生 (2003.3). 《五十二病方》词语拾零. [A Fragmentary Study of Fifty-two Diseases]. Chinese Language.

Onishi Katsuya 大西克也 (1994). 帛书《五十二病方》的语法特点. [The Grammar Features of Fifty-Two Diseases]. 马 王堆汉墓研究文集, [Collections of Mawangdui Han Tomb Unearthed Books], Changsha: Hunan Press.

Qiu Xigui (Chief Edited) 装锡圭 (2014). 马王堆汉墓简帛集成. [Mawangdui Han Dynasty Tomb Bamboo and Silk Books]. Beijing: Zhonghua Book Company.

Qiu Xigui 装锡圭 (1987). 马王堆医书释读琐议. [Notes on Mawangdui Medical Books]. Journal of Traditional Chinese Medicine University of Hunan.

Ren Yingqiu 任应秋 (1984). 马王堆帛书校讹举隅. [Correction on the Interpretation for Mawangdui Medical Books]. Beijing: People’s Medical Publishing House.

Shi Changyong 史常永 (1993). 马王堆汉墓医书考释. [Interpretation on Mawangdui Medical Books]. Chinese Journal of Medical History. 
Wang Jianmin 王建民 (2002). 马王堆汉墓帛书 (肆) 俗字研究. [Popular Form of Characters of Mawangdui Han Dynasty Tomb Bamboo Books (IV)]. Chongqing: Southwestern Normal University.

Wang Yujiao 王玉蛟 (2013). 两汉简帛异体字研究. [Study on the Variant Characters from Han Silk Books]. Chongqing: Southwest University.

Wei Qipeng, \& Hu Xianghua 魏启鹏, 胡翔骅 (1992). 马王堆汉墓医书校释(喜). [Proofreading to Mawangdui Medical Books(I)]. Chengdu: Chengdu Press.

Wu Yunyan 吴云燕 (2006). 马王堆汉墓帛书通用字研究. [Study on the Generally Used Words in Mawangdui Han Silk Books]. Shanghai: East China Normal University.

Yamada Keiji 山田庆儿 (1985). 新发现中国科学史资料的研究. [New Discovery一Study on China’s Science Information]. Kyoto: Institute of Humanity of Kyoto University.

Yan Jianmin 严健民 (2005). 五十二病方注补译. [Additional Interpretation for Prescriptions of Fifty-Two Diseases]. Beijing: TCM Ancient Books Publishing House.

Zhang Ruqing 张如青 (2008.3). 论出土医学文献的整理研究. [Discussion on the Studies of Unearthed Medical Books]. Acta Universitatis Traditionis Medicalis Sinensis Pharmacologiaeque Shanghai.

Zhang Shouren 张寿仁 (2000). 医简论集. [Medical on Set]. Taiwan: Lan Tai Press.

Zhang Xiancheng 张显成 (1997). 简帛药名研究. [In Bamboo-Silk Drug Name Research]. Chongqing: Southwestern Normal University Press.

Zhang Xiancheng 张显成 (2000). 先秦两汉医学用语研究. [In Medical Term Research in Qin-Han Dynasty]. Chengdu: Bashu Publishing House.

Zhang Xiancheng 张显成 (2002). 先秦两汉医学用语汇释. [Glossary of Medical Term in Qin-Han Dynasty]. Chengdu: Bashu Publishing House.

Zhang Zhengxia 张正霞 (2003). 五十二病方构词法研究. [Studies on the Word Formation in Fifty-Two Diseases]. Chongqing: Southwest University.

Zhao Youchen 赵有臣 (1981). 《五十二病方》中 “隋” 字的考释. [Interpretation on 隋 from Fifty-Two Diseases]. Beijing: Cultural Relics Press.

Zhou Yimou, \& Xiao Zuotao 周一谋, 萧佐桃 (1988). 马王堆医书考注. [Notes to Mawangdui Medical Books]. Tianjin: Tianjin Science and Technology Press.

Zhou Zuliang 周祖亮 (2012). 简帛医籍词语研究. [Studies on Words in Bamboo Medical Books]. Chongqing: Southwest University.

Zhou Zuliang, \& Fang Yilin 周祖亮, 方懿林 (2014). 简帛医药文献校释. [Proofreading to Bamboo and Silk Books Medical Books]. Beijing: Xue Yuan Press. 